\title{
Hvorfor fodbold blev massespil i Danmark
}

\author{
af Karl Christensen
}

Fodboldspillet blev første gang præsenteret i Danmark i 1879. Det skete på Eremitagen, hvor Kjøbenhavns Boldklub - KB - viste spillet frem. Nogle år tidligere - i midten af 70-erne dyrkedes spillet dog på Sorø Akademi, hvor en engelsk dreng havde fået tilsendt en fodbold. Men da den efter flittig brug var slidt op; var det for dyrt og besværligt at skaffe en ny. Den første officielle kamp - mellem juniorhold fra KB og Birkerød Kostskole - blev først spillet i 1883, og samme år spilledes den første seniorkamp også med KB som deltager, nemlig mod Orlogsværftet. I de forløbne 4 år siden Eremitagekampen var reglerne fra at være en blanding af fodbold- og rugbyregler, hvor man bl.a. i visse situationer måtte tage bolden med hænderne, erstattet af fodboldregler, såkaldte FA-regler, opkaldt efter den engelske fodboldsammenslutnings (Football Association) regler. Som udformningen af reglerne viser, er spillet importeret fra England til Danmark. Formodentlig har tilrejsende englændere og danskere uddannet i England bragt spillet med sig. Således tyder det på, at KB året før Eremitage-opvisningen havde optaget en klub, The Football Club, bestående af englændere. - Fodboldspillet var således en del af den engelske sport, der begyndende med roningen i midten af 1860-erne, kom til Danmark og hele det europæiske kontinent.

\section{Fodboldspillets udbredelse i Danmark}

I 1880-erne og delvis i 90-erne var fodbold i Danmark et københavnsk anliggende. I denne periode stiftedes en lang række klubber, som holdt til på den københavnske Fælled, bl.a. AB 1884, Frem 1886, B 931893 og ØВ 1894. De her nævnte klubber, som stadig eksisterer, rykkede - med undtagelse af $\varnothing B$ - forholdsvist hurtigt ud fra Fælleden og blev baneejende klubber. Fælleden var dog stadig det centrale sted for spillets udvikling; her dannedes og opløstes mange småklubber, som var mere eller mindre løst opbyggede.

I løbet af 90-erne og især i begyndelsen af det nye århundrede spredtes spillet til Jylland og Øerne. Der var i begyndelsen af 90-erne flere sporadiske tilløb til fodboldspil i Jylland, men først hen mod århundredeskiftet begyndte 
det for alvor. Udbredelsen i Jylland fandt især sted i de store byer og købstæder med Aalborg og Århus som centre, men - hvilket er bemærkelsesværdigt - mindre byer som Vejen, Ringkøbing og Brønderslev manifesterede sig også kraftigt. Den københavnske dominans fortsatte også efter århundredeskiftet; de manglende transportudgifter gjorde det lettere at arrangere kampe i Kbh.-området. Spillemæssigt fik de københavnske klubber inspiration og udvikling gennem kampe mod stærke, professionelle britiske hold. Disse kampe blev gjort til en tradition fra omkring århundredeskiftet, medens Jylland først langt senere fik besøg af disse klubber.

En landsdækkende turnering (cup-turnering) startede i 1913, medens en egentlig Danmarksturnering (point-turnering) startede i 1928. De køben-

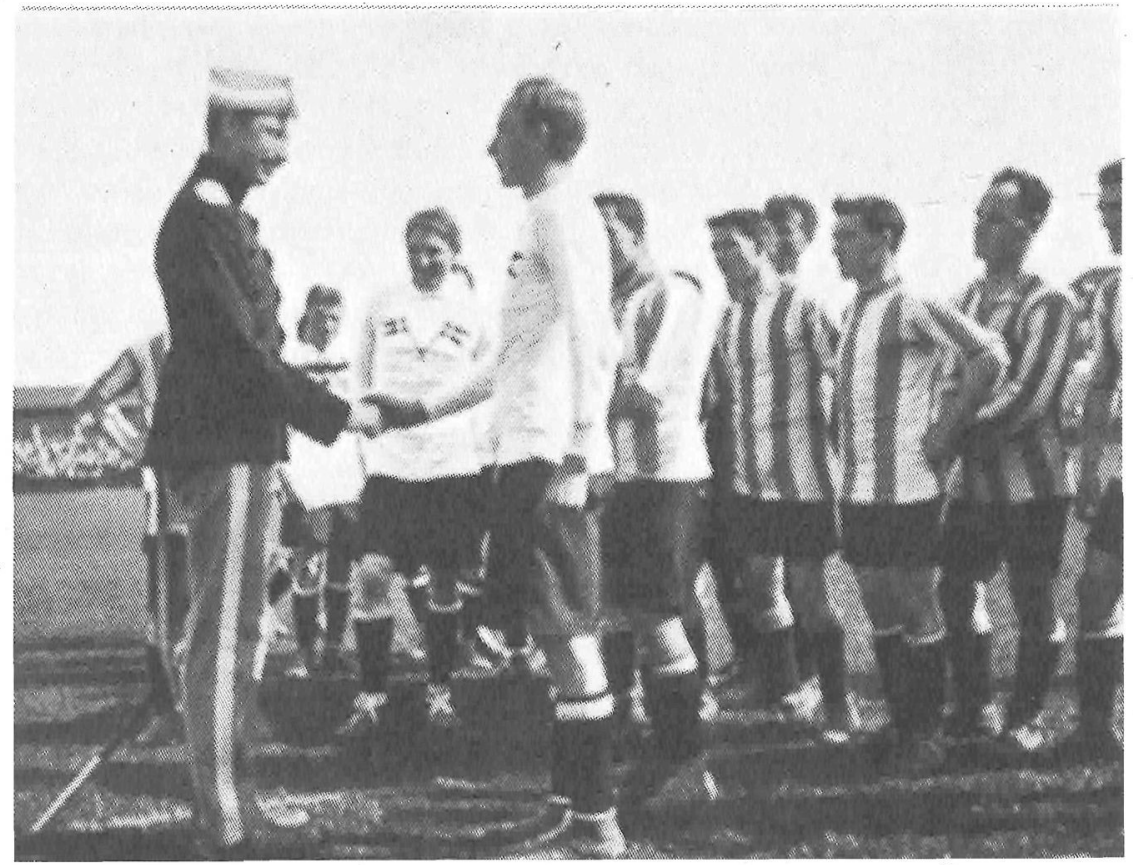

Den første kamp på Idrætsparkens fodboldbane blev spillet d. 25. maj 1911 mellem et udvalgt dansk hold og den professionelle engelske klub Sheffield Wednesday. Før spillet begyndte hilste kronprins Christian på spillerne, og på billedet er det danskernes anfører Kristian Middelboe, som får et håndtryk. Mellem kronprinsen og Middelboe ses målmanden Ludvig Drescher. Dengang havde målmanden samme påklædning som markspillerne, men kunne $i$ almindelighed kendes på, at han spillede med kasket og handsker. 
havnske klubbers dominans varede imidlertid ved helt frem til omkring 1950.

Det sidste trin i fodboldspillets udbredelse, således at det også fik fodfæste på landet og i de mindre byer, synes at have foregået i mellemkrigstiden.

Fra at være et ukendt fænomen indtil slutningen af 1870-erne - og i store dele af landet ukendt indtil århundredeskiftet - er fodboldspillet således allerede i mellemkrigsperioden etableret som langt den største sportsgren $i$ Danmark. En placering som kan opgøres kvantitativt (antal udøvere, klubber o.s.v.), men som sikkert træder endnu tydeligere frem i spillets bevidsthedsmæssige betydning. Dels omkring ens egen deltagelse, dels omkring det ,,at gå til fodbold". Fodboldspillet er blevet en helt selvfølgelig del af hverdagen for mange, og man kan således hævde, at spillet på det nærmeste er blevet synonym med sporten.

Hvorfor er fodboldspillet så blevet en sådan massesport? - er det oplagte spørgsmål, som rejser sig, og som er temaet for denne artikel. Jeg vil belyse problemet fra tre sider, for det første hvorvidt der var tale om, at en bestemt slags klub eller dannelsen af forskellige typer af klubber medvirkede til, at spillet fik en socialt set større udbredelse. For det andet ved at undersøge om der i selve spillet findes elementer, der kan begrunde dets større tiltrækningskraft fremfor andre sportsdiscipliner. Og endelig for det tredie gennem en indkredsning af hvilken funktion spillet havde for mændene, som stod på tærsklen til industrisamfundet. - Artiklen vil bestå i en blanding af konkrete, historiske undersøgelser og mere spekulative overvejelser, der ikke direkte findes historiske belæg for.

\section{Den samme klub?}

Jeg finder det rimeligt at skelne mellem 4-5 forskellige klub-typer, inden for hvilke fodboldspillet har udviklet sig. Klub-typer som i høj grad afspejler forskellige klasser og sociale gruppers liv. Spillet derimod har i sine grundtræk formodentlig været det samme, selv om rammerne omkring det var vidt forskellige. Jeg vil - bortset fra de tidlige københavnske klubber - eksemplificere ud fra de århusianske fodboldklubbers historie.

\section{Fælledklubber:}

Som ovenfor nævnt var Fælleden i København et kraftcenter for udviklingen af spillet. De mange små klubber, som dannedes i 1880-erne og 90-erne og 
efter århundredeskiftet havde både mærkelige og fantasifulde navne. ${ }^{1}$ Fremtiden, Apollo, Mjølner, Fix, Pollux, Skjold, Flink, Clythia. Andre af klubnavnene afspejlede derimod medlemmernes beskæftigelse: Cigararbejdernes Sportsklub, Skræddernes Sportsklub, Lærlingehjemmets Klub. De fleste af klubberne havde en ret kort levetid. Spillerne i disse mere eller mindre løst organiserede klubber var stort set arbejdere og håndværkere.

Omklædningen fandt i begyndelsen sted på Fælleden, senere blev haver til nærliggende beværtninger eller lejede værelser taget $\mathrm{i}$ brug. Målene var oftest sten- eller snoremål, som kunne fjernes igen, når Fælleden skulle bruges til andre formål, såsom borgerbevæbningens ekserceren eller dyrskuer.

Borgerklubber:

Også de københavnske borgerklubber startede på Fælleden. I løbet af nogle àr rykkede disse klubber ud fra Fælleden til egne baneanlæg, ofte flotte anlæg udstyret med pavillon og omklædningsrum. KB fik eget anlæg i 1894, B 93 i 1901, AB i 1902. OB - Odense Boldklub - fik som den forste uden for København i midten af 90-erne, og AGF fik som den første jydske klubi 1909.

Rimeligheden $i$ at benævne disse klubber for borgerklubber kan ses ud fra flere forhold. For det første at de som nævnt var så økonomisk velfunderede, at de kunne erhverve egne anlæg. For det andet at medlemmerne overvejende var borgerskabs- og mellemlags (d.v.s. offentligt ansatte og længerevarende uddannede) mænd. Dette afspejles i grundlæggernes og medlemslisternes stillingsbetegnelser. ${ }^{2}$

„Fra de første faa blev „KB“ den lille, ret eksklusive Klike, Tennisspillet præget af Diplomati og Upper-ten, Fodbold og Kricket navnlig af Studenter og Bourgoisi.

Kredsen voksede efter at „KB“ i 1894 havde faaet sit Marcusalléanlæg; men endnu langt op i de første internationale Fodboldkampes Dage eksisterede faktisk Idyllen endnu."

(Kjøbenhavns Boldklub 1876-1926. Kbh. 1926, s. 4.)

For det tredie ved træk i klubbernes sociale liv: ud over fodboldspillet afholdtes baller, maskerader, aftenunderholdning samt flere dages udenlandsrejser. Og der blev stillet krav til medlemmerne: B 93 betegnede sig selv

1. Lauritz Jensen: „,Fælledernes fodbold før og nu“, i A. Herman \& E. Andersen: Den danske Idræts Bog, Kbh. 1935.

2. F.eks. i Festskrift ved Aarhus Gymnastikforenings 25 Aars Jubilæum, Aarhus 1906, hvor der s. 81-84 findes en fuldstændig medlemsliste med stillingsangivelser. 
som en eksklusiv klub, $A B$ optog kun medlemmer, som studerede ved Universitetet eller Polyteknisk Læreanstalt. Endelig kan man ved at studere gamle billeder fra disse klubber aflæse et vist selvværd og betydelig selvfølelse i påklædningen og posituren foran fotografen.

AGF - Aarhus Gymnastik Forening - blev dannet som gymnastikforening i 1880. I 1902 blev fodboldspillet taget op i klubben:

„Frygtindgydende saa de ud, hin Tids Fodboldkæmper, om end knap saa fikse som Nutidens Helte fra Grønsværet; ofte iført de lange Benklæder og den ærmeløse Trøje, som man ogsaa havde Brug for til Gymnastikken; dertil nu og da, maaske for at betegne Spillets Karakter, formidable Benskinner - udenpaa! Fodtøj, der var særlig beregnet og hensigtsmæssigt for denne Idræt, kendtes derimod ikke straks, og det var forbeholdt den gamle Soraner, cand. mag. Ax. Bang at demonstrere dette senere saa selvfølgelige Apparat. (...) Den, der skriver disse Linier, erindrer endnu at have beundret ærede Medborgere som Lind, Leipziger, Ax. Müller og Georg Ølsgaard i de tidlige Aftentimer tumle sig i vældig Dyst paa Pladsen langs med Kasernen, og navnlig beundret den Behændighed, hvormed man forstod at undgaa de Snore, der for at holde Maalstængerne fast og Overliggersnoren stram var udspændt som Barduner langt ind paa Banen."

(E. Kirkegaard: AGF. Aarhus Gymnastikforening 1880-1930, Aarhus 1930, s. 26-27.)

De første år blev spillet udviklet $\mathrm{i}$ tæt samarbejde med Marselisborg Kostskole. Man spillede træningskampe mod skolen, og AGF måtte bruge skolens fine faciliteter. Som nævnt byggede klubben eget anlæg i 1909 på området for den netop afholdte landsudstilling, og pavillonen herfra blev overtaget af AGF. I løbet af få år - 10-15 år - blev fodboldafdelingen foreningens største. Et forhold som også sås i mange andre klubber: fodboldspillet kom ind $i$ en allerede etableret klub og fortrængte andre discipliner, oftest cricket.

Bevidstheden om klubbens placering $i$ byens liv træder frem omkring formandsskiftet i 1918, hvor direktør Lausen afløses af fabrikant Wied:

„A.G.F. har gennem alle de Aar, den har eksisteret, stedse søgt at faa Formandsstillingen beklædt med saa fremragende en Borger som muligt. Den gamle Forening har haft en Række Formænd, hvis Anseelse og værdifulde Egenskaber i høj Grad har bidraget til at højne og kaste Glans over dens Arbejde.

(...) Formandsstillingen i A.G.F. er uimodsigeligt den aarhusianske 


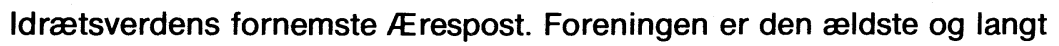
den største Idrætsforening uden for København. Med sine ca. 860 Medlemmer spænder den over alle Samfundslag her i Byen. Blandt de passive medlemmer finder man flere hundrede højt ansete aarhusianske Navne, og selv om de fleste af disse Medlemmer kun sjældent ses ved Foreningens Møder og Sammenkomster, saa svigter de aldrig paa de store Mærkedage og heller ikke, naar Foreningen $i$ en eller anden Anledning Appellerer til dem."

(leder i A.G.F. Medlemsblad for Aarhus Gymnastikforening. 1. årg. prøvenr. Århus 1918).)

AGF blev omdrejningspunktet for dannelsen og udviklingen af de århusianske klubber op gennem århundredet. Og i dette udviklingsforløb - som kan genfindes mere eller mindre modificeret $i$ andre byer afhængigt af byernes størrelse - dukker også de øvrige klubtyper frem.

Arbejderklubber:

Fælledklubberne var for manges vedkommende dannet af arbejdere. Men de var ikke dannet som egentlige politiske klubber med socialistisk eller socialdemokratisk sigte. Der findes dog klubber dannet med et klarere arbejderpolitisk sigte. Det var arbejderklubber, som opfattede sig selv $i$ opposition til de fine klubber. Klubberne ønskede dog ikke at ændre på selve fodboldspillet og dets regler. Spillet var tværtimod stedet, hvor man kunne hævde sig, føle sig værdige - og i nogle tilfælde ovenikøbet banke de fine. Det sociale liv var formodentlig forskelligt fra borgerklubbernes. Klubberne foretog kortere rejser til venskabsbyer, hvor dagen ofte startede med optog gennem byen. I egen selvopfattelse var der større fællesskab og solidaritet $i$ klubben, ofte vokset frem i det praktiske arbejde omkring at skaffe klubhus og andre faciliteter.

I Århus blev AIA - Arbejdernes Idrætsklub i Aarhus - dannet af utilfredse AGF-medlemmer i 1918. I de første år krævedes fagforeningsmedlemskab for at blive optaget $i$ klubben. Ret hurtigt blev det store mål at hævde sig $i$ kampen med AGF om at være den stærkeste i byen. Der var på det nærmeste tale om folkefest, når AIA og AGF mødtes i 30-rne og igen i 50-erne. Et stort AlA-banner med teksten: „Der er andre end AGF der dur!” medbragt på stadion til en af kampene i 30-rne illustrerer måske meget godt forholdet klubberne imellem. 
Disse arbejderklubber adskilte sig således mest fra borgerklubberne gennem den sociale rekruttering og klublivet, medens det klare politiske sigte hurtigt fortonede sig. Anderledes med den organiserede arbejderidræt i 30-rne, som blev dannet med et klart politisk mål. Socialdemokratiet ønskede at komme en kommunistisk organisering af arbejderidrætten i forkøbet og skyndede derfor kraftigt på oprettelsen af arbejderklubber. Det politiske indhold var imidlertid ofte af ydre, skolingsmæssig og propagandistisk art. Fodboldspillet blev et middel i den politiske kamp, medens selve spillet ikke blev ændret eller påvirket. I Århus dannedes i den forbindelse ASA - Arbejdersport, Aarhus - $\mathrm{i} 1933$.

Kvartersklubber:

Underlegenhedsfølelsen og ønsket om at hævde sig - som AlA-banneret udtrykte - var også en del af grundlaget for kvarters-klubberne. Men dog ikke det hele. Klubberne opstod $\mathrm{i}$ mellemkrigstiden, hvor der var opstået store arbejder- og småborger- (handlende og mindre virksomheder) kvarterer, og hvor hverdagslivet struktureret omkring lønarbejdet lå fast. Kvartererne var ret afgrænsede territorier med gadelivet som det fælles og offentlige rum. Fodboldklubberne fik noget af den samme funktion som både offentligt og privat område. Man kendte de øvrige, som kom der, og man kendte reglerne for optræden. Formodentligt var samhørigheden mellem klubberne og tilskuerne størst $i$ denne type klubber. En fodboldkamp var en form for kvarterets fest - dog nok mest en fest for mændene.

I Århus dannedes bl.a. Skovbakken, Fuglebakken og Christiansbjerg Boldklub (CB) som sådanne klubber. Skovbakken blev dannet 1927 på Trøjborg, igangsat af to boligforeninger. Det hedder om klubben i dets jubilæumsskrift:

„Vil man bestemme „Skovbakken"s særlige karakter som idrætsklub, bør man altså ikke ensidigt studere rekordtavlerne, men orientere sig på bredere basis. Typisk for "Skovbakken" er dens samhørighed med bydelen, hvori den har hjemme. Typisk er endvidere dens idealistiske syn på idrætten samt dens arbejdsmåde. ,,Skovbakken“ er kvarterets idrætsklub fremfor nogen. Navnet har den fra villabyen „,Skovbakken“ (...).

(...) Det er kvarterets børn og unge, som figurerer i medlemsfortegnelserne. Lederne er fortrinsvis kvinder og mænd med fast rod i kvarterets grund. Og de mange trofaste tilhængere, som lever med i klubbens liv, er hovedsagelig kvarterets beboere."

(Idrætsklubben Skovbakken, Århus 1927-52, Århus 1952, s. 7-8.) 
Klubben var central i kvarterets liv: arrangerede skoleidrætsstævner, Sct. Hansfester, byggede eget stadion, havde eget orkester og sangbog. Karakteristisk for kvartersklubberne var den hastige vækst i medlemstal. De tæt bebyggede kvarterer gav mulighed for store ungdomsafdelinger, hvilket også gjaldt for Skovbakken.

CB blev stiftet $1935 \mathrm{i}$ et arbejderkvarter $\mathrm{i}$ den nordlige del af byen, og Fuglebakken dannedes i den vestlige del af byen 1944.

\section{Landklubber:}

Med fælled-, borger-, arbejder- og kvartersklubberne har jeg skitseret fodboldspillets udvikling i byerne. Men spillet bredte sig også ud på landet, til de mindre byer og landsbyerne. Landklubbernes historie er det dårligst belyste område af spillets historie. Der fandtes ikke - som i England - et gammelt folkekulturelt spil, som blev taget op igen. De gamle danske boldspil var af en anden karakter.

Landklubberne blev for de flestes vedkommende dannet i mellemkrigsperioden. Måske min egen barndomsklubs opståen er ganske typisk. Klubben blev stiftet i 1929, hvor den i en del år deltog i stævner og pokalturneringer, før indmeldelsen $\mathrm{i}$,,den rigtige turnering “ under JBU. Opdelingen mellem gymnastik og fodbold på egnen var skarp, ikke kun således at gymnastikken var vinteridræt og fodboldspillet sommeridræt, men også blandt mange af udøverne. Først omkring 1960-erne begyndte gymnastik-karlene at svigte gymnastikken til fordel for sporten. Den kulturelle betydning som et af samfundets samlingssteder kunne i de første mange år ikke stå mål med gymnastikforeningens centrale placering.

Spillet på landet var - og er tildels stadig - underlagt en større naturbinding; det var svært at samle hold i høstperioden.

Helt fra starten var klubben præget af, at spillerne kom fra et lille, afgrænset område, hvor alle kendte alle. Man var aldrig anonym: navne, familieforhold, kæresterier og om man var hård til at drikke ved ballerne var altsammen fællesviden. I mange tilfælde eksisterede også et arbejdsfællesskab blandt spillerne. Et stærkt socialt sammenhold - og tæt sammenvokset hermed også en stærk social kontrol - blev således ført med ind i klubben. Udfoldelsen på og uden for banen foregik inden for nogle klare og velkendte roller - men dog formodentligt betydeligt friere end ved mange af de øvrige fælles arrangementer på egnen.

De forskellige klubtyper beskrevet ovenfor viser, at fodboldspillet har fascineret og grebet mændene i mange grupper - både borgerskab, småborgerskab, mellemlag og arbejderklasse. Og denne socialt set brede rekruttering berettiger til at benævne spillet en massesport. 
Interessant er det, at den danske historie både ligner den engelske og alligevel viser andre, specifikke danske træk. Spillets udvikling her i Danmark hænger givetvis tæt sammen med industrialisering, urbanisering og transportformernes udbredelse, men udviklingen kan dog ikke beskrives $i$ helt så klassespecifikke processer som den engelske. I England blev det gamle folkefodboldspil - som skildret af Claus Nielsen i den foregående artikel - på kostskolerne omdannet til det moderne fodboldspil, der hurtigt spredtes til resten af samfundet og omkring århundredeskiftet helt var koloniseret af arbejderklassen.

Der var ikke i Danmark i sidste halvdel af 1800-tallet og begyndelsen af 1900-tallet den samme udprægede dikotomi mellem borgerskab og arbejderklasse som i England. Den danske industrialisering var for en stor del igangsat af landbrugets stærke økonomiske stilling, således at småborgerskabet og småproduktionen stod stærkt. Kulturelt set spillede bondekulturen omkring grundtvigianisme, højskoler og andelsbevægelse en stor rolle. Og på kropskulturens område var gymnastikken dominerende. Sportens udbredelse forløb derfor forholdsvis langsomt. - Alligevel synes det klart, at fodboldspillet var igangsat af borgerskabet og mellemlagene, specielt $i$ de mange klubber, der startede som cricket-klubber. Senere har spillet så bredt sig ud til arbejderklassen og småborgerskabet. Men nogen overtagelse eller kolonisering efter engelsk mønster har der ikke været tale om, bl.a. har arbejderklassens relativt svagere stilling i Danmark sikkert medvirket til, at professionalismen ikke blev indført med spillets udbredelse her i Danmark, som det skete i England.

\section{Fodboldspillets egenart}

Et næste spørgsmål, som melder sig, er, om man kan pege på specielle elementer $\mathrm{i}$ spillet som forklaring på dets voldsomme udbredelse. Det har tidligere været hævdet $-i$ en kritik af spillet ${ }^{3}$ - at spillet og $i$ det hele taget sporten og fritidslivet blot kompenserede for arbejdslivets strabadser, og at træk fra arbejdslivet såsom disciplin, autoritetsforhold og økonomisk tvang også fandtes $\mathrm{i}$ fodboldspillet. Fodboldspillets lighed med industriarbejdet skulle således forklare dets popularitet. En sådan forklaring synes langt fra dækkende, f.eks. ophæves adskillelsen mellem hånd og ånd - som er et af industriarbejdets vigtigste træk - $i$ fodboldspillet, og i det hele taget overses en lang række af spillets sider ved en sådan forklaring. Jeg vil i stedet

3. Kraftigst fremført af den tyske såkaldte ideologikritiske skole med bl.a. J. Habermas og G. Vinnai som eksponenter. 
focusere på følgende tre træk: spændingen, den kropslige udfoldelse og individ/gruppe-dynamikken.
„Men det er ikke for meget sagt, at Gymnastikken i Foreningen som andet Steds er blevet stillet i Skygge af sin langt yngre Søsterdisciplin: Spillet med den faste Læderkugle, Fodbolden. Aarsagerne ligger ganske lige for: Friluftsidrætten, den fælles Opgaaen i Samfølelse mellem Spillerne og det stadige Spændingsmoment er Faktorer, der vejer tilstrækkelig tungt."
(E. Kirkegaard: AGF. Aarhus Gymnastikforening 1880-1930, Århus 1930.)

Spændingen kan betragtes som en spændingsbalance 4 mellem to grupper, der står over for hinanden. Der opbygges hele tiden polariteter, som holder spændingen vedlige. F.eks. mellem samarbejde og konflikt internt på holdene, mellem forsvar og angreb, mellem nydelsen ved at få aggressionerne ud $\mathrm{i}$ spillet og reglerne som hindrer dette, mellem to hold. Spillernes hurtige bevægen sig rundt på banen gør, at disse spændingsforhold til stadighed veksler og skifter. Denne spændingsbalance findes imidlertid ikke kun i fodboldspillet, men i gruppeforhold i det hele taget.

Man kan imidlertid pege på to andre forhold, ${ }^{5}$ som er mere specifikke for fodboldspillet, nemlig målscoringens og tidens betydning. Målscoringen har en ,,afslutningskarakter" à la boksningens knock out, der er helt forskellig fra f.eks. håndbold- og basketballspillets scoringssituationer. En modstanderscoring indhentes langt lettere i disse boldspil. Målscoringen havde ikke den samme centrale betydning i folkefodboldspillene, slagsmålene undervejs spillede en større rolle.

Tiden er vigtig, fordi en kamps varighed nøje er fastlagt. Kampens forløb har hele tiden som forudsætning, at der resterer et bestemt antal minutter, således håbet om udligning og sejrsmål altid knytter sig til afslutningstidspunktet. Tiden spillede en hel anden rolle $i$ folkefodboldspillet, kampen kunne vare i flere dage. Denne forskel $i$ tidens betydning illustrerer meget vel industrisamfundets lineære tidsopfattelse, der afløste den tidligere mere cykliske opfattelse. Endelig består spændingen også i de faste ritualer, som spillere og publikum - ofte i forening - bygger op. Der skabes altid helte og ofre, og ,vi" over for "de andre" er også et fast holdepunkt omkring en fodboldkamp.

4. Se Norbert Elias \& Eric Dunning: „Dynamics of Sport Groups with Special Reference to Football“", i E. Dunning: The Sociology of Sport, London 1970.

5. H. Eichberg: Leistung, Spannung, Geschwindigkeit, Stuttgart 1978. 
Den kropslige udfoldelse er en stor del af fodboldspillet, spillet opleves gennem kroppen: fornemmelsen af de perfekte eller mislykkede skud, afleveringer, tacklinger o.s.v. sidder i kroppen.

Historisk set var der tale om helt andre udfoldelsesmuligheder end resten af hverdagen gav mulighed for. Med udfoldelsen i spillet fulgte sikkert også en vis disciplinering à la arbejdets disciplinering af arbejderne. Man måtte underkaste sig spillets regler og arbejdsdeling. Men, som især engelske kulturhistorikere har hævdet, lægger spillet op til fælles deltagelse og opdragelse. Og oplevelsen af en fælles sejr har givetvis modvirket erfaringerne af kontrol og underkastelse på arbejdspladsen.

Forholdet mellem individ og gruppe er formodentligt af stor vigtighed for at forstå spillets fascinationskraft. ${ }^{6}$ Selv om hver spiller på forhånd har en bestemt plads på holdet og dermed ofte en afgrænset del af banen at bevæge sig på, ja selv hvor alle spillere på et hold har faste markeringsopgaver, kan indholdet og udviklingen i en fodboldkamp ikke programmeres. Den enkelte spiller vil altid - alene eller i sammenspil med andre - foretage sig noget, der rækker ud over dette mønster. Uventede situationer vil opstå, og heri findes meget af dynamikken $i$ fodboldspillet. Den enkelte spillers udfoldelse er således fundamentet for spillet, men er samtidig aldrig alene tilstrækkelig. Udviklingen af holdspillet er afhængigt af, at de enkelte spilleres spil går op i hinanden, og først i holdspillet ses betydningen af den enkelte handling.

Jeg mener, at spændingen og individ/gruppe-forholdet er de to vigtigste elementer for at forstå spillets dynamik. Individ/gruppe-forholdet adskiller spillet fra ikke-holdsporterne, og spændingen, specielt omkring målscoringens betydning, adskiller spillet fra de øvrige holdsporter.

\section{Mændenes fodboldspil}

Fodboldklubberne - lige fra fælledklubberne og fremefter - har alt overvejende været mændenes. Det var mændene, som spillede, og det var flest mænd, der kiggede på.

Jeg har ovenfor skitseret, hvorledes mændene afhængigt af deres sociale tilhørsforhold gik til forskellige klubber. Men spillet var stort set det samme i

6. Dette spændingsforhold er glimrende beskrevet af J.-P. Sartre i W. Uesseler: ,Jean-Paul Sartre som fodboldspillets teoretiker", i Bidrag nr. 13/14, Odense 1981. Sartre bruger fodboldspillet eksemplificerende.

3 Idrætshistorisk Årbog 
de forskellige klubber, og jeg pegede på nogle af de elementer i spillet, som formodentligt medvirkede til at gøre spillet til et massespil. Måske kan yderligere en del af forklaringen på spillets udbredelse findes ved at indkredse hvilken funktion spillet havde for mændene omkring industrialismens gennembrud i Danmark. Jeg finder det rimeligt at fremhæve to områder, hvor spillet sandsynligvis har haft stor betydning. For det første som stedet for opfyldelse af nogle utopiske behov og for det andet som stedet, hvor mandigheden kunne stives af.

Nødvendigheden af et utopisk perspektiv kan begrundes $i$, at oplevelsen af konflikter og utilfredshed med tilværelsen jo er et udtryk for troen på, at noget andet og bedre er muligt. At det faktisk er muligt at finde den meningsfuldhed og sammenhæng, som mangler $i$ ens tilværelse. Og fodboldklubberne og spillet kan så betragtes som eet af de steder, hvor en sådan meningsfuldhed kan findes. Sporten har så at sige helet en række historiske brud og mangelsituationer opstået specielt omkring industrialiseringen og kapitalismens start. En tese, som er fremført af Niels Kayser Nielsen. ${ }^{7}$

Mange af de tidlige klubber, fælledklubberne og arbejderklubberne udfyldte formodentlig en længsel tilbage mod livet på landet, en såkaldt regressiv utopi. En stor del af spillerne var 1. generationsarbejdere brudt op fra en tilværelse på landet præget af betydelig større overskuelighed, naturtæthed og fællesskab med andre. Den nye tilværelse i byerne var på flere punkter en mangelsituation, fordi de kulturelle institutioner og samværsformerne fra landet manglede. Isolationen var større.

Fællesskabet, den kropslige udfoldelse og naturkontakten kunne opfyldes netop i fodboldspillet. Det legemoment, som mere og mere forsvandt i det industrielle arbejde, kunne holdes vedlige i spillet. Samtidig med at ,,længslen tilbage" blev opfyldt, passede spillet dog også til bylivet. Den generelle kropsdisciplinering og -beherskelse, som sætter ind med industrialiseringen, var også nødvendig i spillet ved siden af den rene fysiske styrke. Den lineære tid var også en del af spillet, selv om nok specielt spillet i de små klubber var præget af både en cyklisk og en lineær tidsopfattelse. Der findes både uskrevne regler som på landet og skrevne, formelle regler, der i højere grad hører til det nye industrielle liv til.

Spillets utopiske funktion pegede ikke kun bagud mod landet, men også fremefter med opfyldelsen af demokratiske friheds- og lighedsidealer. Selve

7. Omkring en sådan utopisk forklaring på fodboldspillets udbredelse bygger jeg kraftigt på Niels Kayser Nielsen: „Sport, kultur og utopi“, i Bidrag nr. 13/14, Odense 1981. 
sportens fundament er lighed for alle og frihed inden for et fællesskab - og den lighed, som ikke fandtes i det danske samfund omkring århundredeskiftet kunne måske opfyldes inden for sporten. Både fælled-, arbejder- og kvartersklubber havde sådanne lighedsønsker, måske tydeligst hos de to sidstnævnte typer. AlA dannedes som nævnt som en protest mod de fine fra AGF og søgte på samme måde som de århusianske kvartersklubber at hævde sig over for AGF, blive ligeværdige. Men lighedskravet inden for sportens verden var ofte et idealkrav, som ikke kunne indfries. Social status og økonomisk formåen mærkedes også her. F.eks. illustrerer følgende bitre bemærkninger fra AIA de økonomiske problemers betydning. Klubben anmoder fagforeningerne om hjælp til bl.a. dækning af et stævneunderskud og til et klubhus:

\begin{abstract}
,Alle andre Idrætsforeninger her i Byen har adskillige Velyndere, som betaler eventuelle Underskud, og tillige sørger for Anskaffelse og Vedligeholdelse af Rekvisitter. Da A.I.A., som er et Arbejderforetagende, ikke har de fornødne økonomiske interesserede, er det, at vi henvender os til Fagforeningerne om økonomisk Støtte."

(Brev fra AIA, 1924.)
\end{abstract}

Fodboldspillet synes for det tredie - $i$ kvartersklubberne - at have ophævet en del af den opsplittethed, medlemmerne oplevede dagen igennem mellem arbejdet, det private liv og det offentlige liv. Altså en slags heler af hverdagslivets brud. Klubberne opstod i mellemkrigstiden, hvor arbejderne ikke længere var 1. generationsarbejdere. Hverdagen centreret omkring lønarbejdet lå fast.

Een af de værdier - mandigheden som iflg. engelske kulturhistorikere ${ }^{8}$ er afgørende for spillets placering i den engelske arbejderkultur, kan trækkes frem for at finde endinu en del af forklaringen på fodboldspillets succes. I sin undersøgelse af mandlighedens historie skelner Steffen Kiselberg ${ }^{9}$ mellem forskellige faser. To væsentlige udviklinger $\mathrm{i}$ fodboldspillets historie kan måske belyses herigennem. Eller fodboldspillet har måske ovenikøbet haft betydning for mandlighedens udvikling.

For det første omkring det moderne fodboldspils udformning på de engelske kostskoler. Spillet var et vigtigt middel til opdragelsen af handle-

8. Bl.a. Ian Taylor: ,,,Football Mad": A speculative Sociology of Football Hooliganism", i E. Dunning: The Sociology of Sport, London 1970, og John Clarke: „Fodbold og arbejderklassefans: tradition og forandring", i Bidrag nr. 13/14, Odense 1981.

9. Steffen Kiselberg: Mændenes historie, Kbh. 1979. Kiselberg beskæftiger sig ikke med fodboldspillet. 
kraftige og selvstændige ledere. Der var tale om karaktertræning, hvor værdier som selvbeherskelse, gruppeloyalitet, samarbejde, konkurrence inden for regler og evnen til at træffe hurtige beslutninger var fremherskende. ${ }^{10}$ Altsammen træk, som passer til den "traditionelle borgerlige manderolle" karakteriseret ved rationalitet og nyttekalkulation - mandlighedens første fase iflg. Kiselberg. Den traditionelle manderolle udvikledes formodentlig mere eller mindre klart inden for alle fodboldklubber, men jeg vil dog mene, at karaktertræningen og vægten på den borgerlige dannelse var stærkest $i$ borgerklubberne. Mottoet „Tab og vind med samme sind“, som f.eks. KB har gjort til sit, er i så henseende eksemplarisk. Medens „Hellere brække en arm end tabe en kamp" (een af den gamle fælledklub B 1903's slagord) og kvarterklubbernes insisteren på at hævde sig over for de fine ikke er udtryk for helt det samme dannelsesideal. Og i den meget brugte formulering ,At gøre drenge til mænd" - ved at bruge sporten som opdragelsesmiddel tænkes ofte på den samme karaktertræning.

For det andet mandlighedens anden fase - kaldet "mandigheden" omkring år 1900. Mandeidentiteten var blevet et problem, således at der opstod et slags mandighedssyndrom, hvor mandigheden blev dyrket og bekræftet. Mandighedssyndromet udvikledes som et slags svar på „truslen“ mod mændenes kønsidentitet. En trussel der, iflg. Kiselberg, var specifik for arbejderklassen, hvor mandens position var truet, dels på grund af en stigende umyndiggørelse $\mathrm{i}$ arbejdslivet med den industrielle arbejdsdeling, dels på grund af at han var fraværende fra hjemmet det meste af dagen. Denne trussel resulterede så i udviklingen af en ,,proletarisk mandighedskult" ", der bl.a. lagde stor vægt på kraft og styrke.

Tidsmæssigt synes fodboldspillets udbredelse og mandighedssyndromets udvikling således at falde sammen. Begge udviklinger fandt sted omkring århundredeskiftet, tydeligst for Englands vedkommende, hvor arbejderklassen koloniserede spillet, men også i et vist omfang her i Danmark. Der er ingen tvivl om, at fodboldspillet - både for spiller og tilskuer - gav gode muligheder for anvendelse af netop den fysiske styrke; spillet var generelt præget af fysisk hårde tacklinger. Slægtsskabet med rugby var stadig tydeligt, selv om den fysiske udfoldelse blev reguleret mere og mere gennem forskellige nye regler. Og givet er det, at omklædningsrummets ,mandehørm" også dengang har indeholdt den samme brovten, chauvinisme og selvbekræftelse som nu. - Jeg finder dog, at fodboldspillet trods alt indeholder en hel del flere kvaliteter end blot erstatning for den tabte mandighed. Bl.a. den kropslige udfoldelse og individ/gruppe-dynamikken, som jeg be-

10. Folkefodboldspillets omdannelse til det moderne fodboldspil på de engelske kostskoler er først og fremmest skildret af Eric Dunning. 
skrev tidligere, samt ikke mindst den større åbenhed og ærlighed, som er en anden og uadskillelig del af mandehørmen.

\section{Afs/utning}

Jeg har søgt at indkredse, hvorfor fodboldspillet er blevet massesport i Danmark. Den store udbredelse kan aflæses i de forskellige klubtyper. Klubberne, inden for hvilke spillet blev udviklet, rekrutterede medlemmer i forskellige klasser og grupper, og klubbernes sociale liv var langt fra ens. Spillet var imidlertid det samme, og jeg pegede på tre elementer, hvorved fodboldspillet adskilte sig fra de øvrige sportsdiscipliner, og individ/gruppedynamikken var formodentlig væsentlige for at forstå, hvorfor netop fodboldspillet - og ikke f.eks. roning eller atletik - blev massesporten i Danmark. Endelig argumenterede jeg for, at man kan se på fodboldspillets funktion for mændene omkring industrialismens gennembrud, og herigennem finde en del af årsagen til spillets popularitet. Spillet synes at have opfyldt mange af de huller og mangler, som industrialiseringens hastige ændring af samfundet bevirkede for menneskene. Det drejede sig bl.a. om problemer i.f.m. opbrud fra landet og flytning til byen; det drejede sig om hverdagslivets opsplittethed, og det drejede sig om problemer med den mandlige kønsidentitet.

En lang række forbehold og nuanceringer er sikkert påkrævede, f.eks. kan det diskuteres, hvorvidt en opdeling i forskellige klubtyper i det hele taget er muligt. Og i en lang række tilfælde vil det konkret være vanskeligt at karakterisere en klub som den ene eller den anden type. Alligevel mener jeg, at den fremlagte skitse giver en væsentlig del af forklaringen på fodboldspillets udvikling til massesport.

Artiklen bygger på mit speciale, fodboldspillet - teori, historie og fascination, afleveret ved Institut for Statsk./Samf. i 1983. Heri findes også en mere udførlig litteraturhenvisning. Udover klubbernes jubilæumsskrifter og medlemsblade - specielt for de århusianske klubbers vedkommende - har jeg omkring de historiske forhold især anvendt Johs. Gandil: Dansk Fodbold, Kbh. 1935 og A. Alstrup: Jysk fodbold i fortid og nutid, Odense 1950. 
